\title{
Developments in SLA and L2 Research on Psychological and Emotional Factors: A bird's-eye view
}

\author{
Larisa Nikitina \\ University of Malaya \\ Correspondence concerning this article should be addressed to Larisa Nikitina, Faculty of Languages and \\ Linguistics, University of Malaya, 50603 Kuala Lumpur, Malaysia. Email: larisa.nikitina@gmail.com
}

This special issue of Journal of Language and Education is devoted to psychological and emotional aspects that saturate a language learning - and a language teaching - endeavour. Learning a second or a foreign language (L2) is one of those human activities that, besides drawing upon a person's cognitive resources, involves a multitude of psychological and emotional factors. For this reason, language learning as an activity and process has attracted a considerable interest from psychologists, applied linguists and language educators.

While it is not possible to pinpoint exactly when this interest first appeared, psychology of language learning as a topic of scholarly inquiry dates back to the early decades of the $20^{\text {th }}$ century. Russian psychologist Lev Vygotsky (1896-1934) was among pioneer scholars who provided deeper understanding of a complex nexus of cognitive, psychological and effective processes embedded in children's language learning endeavours, be it the learning of the mother tongue or second language. Nevertheless, as Vygotsky's argumentations in K voprosu o mnogoyazichii $v$ detskom vozraste ('The question of multilingual children', 1935) and Myshlenie i rech ('Thinking and speech', 1934) attest, the cognitive - rather than the affective -- processes was the primary interest of his fellow psychologists working in Russia and abroad in the first quarter of the $20^{\text {th }}$ century.

Eventually, social psychological perspectives on learning an additional language became prominent. Of a particular interest to the researchers were attitudes that language learners hold toward target language communities and target language itself. Seth Arsenian was the first psychology scholar to propose existence of a relationship between language learners' attitudes toward the other language community and achievement in learning the target language (Gardner, 1988). Notably, Arsenian's review of contemporary studies in second language acquisition (SLA) identified "the social psychology of language and bilingualism" as one of the research topics that received a considerable attention from scholars (Arsenian, 1945, cited in Gardner 1985, p.2). Among the questions that greatly stimulated this interest were: Does communicating with another language community promote understanding and warmth? Can people learn a new language successfully if they do not like the community that speaks this language? Are sociable individuals more successful language learners?(Gardner, 1985).

In other words, in the mid- $20^{\text {th }}$ century the process of learning an additional language was recognized as a social psychological phenomenon. This was a major shift from viewing the learning of a new language as a purely cognitive activity where emotional, volitional and affective factors played only a minor role. The boundaries of SLA/L2 research greatly expanded as a result of a growing awareness of the role that various social factors and prevailing attitudes play in language learners' views of target language communities and in determining a successful outcome of their language learning efforts. So it was only a matter of time that language learners' individual differences began receiving increasing attention in research studies. Many of such studies were driven by a search for answers to an overarching question: Why some individuals become fluent speakers of one or more foreign languages while others remain monolingual? (Gardner, 1985).

An important milestone in research on language learners' individual differences occurred in the year 1959, when Robert Gardner, who was at that time a PhD student in psychology in McGill University, and his thesis supervisor Wallace E. Lambert published a highly influential article "Motivational variables in second-language acquisition". The researchers explicitly operationalized attitudes that Canadian English-speaking learners of French were holding toward the target language community as a motivational construct. They named this construct 'integrative orientation'. As Gardner and Lambert found, the students with positive attitudes toward 
the target language community were more motivated and more successful language learners. The pioneering research by Gardner and Lambert $(1959,1972)$ led to an upsurge in scholarly inquiries on motivation to learn an additional language (L2 motivation). In 1985, Gardner's book Social psychology and second language learning: The role of attitudes and motivation was published and the socio-educational model of second language acquisition proposed by him was formalized.

Issues and problems concerning L2 motivation and its ebbs and flows retain the great fascination for applied linguistics researchers and language educators. As Mercer, Ryan and Williams (2012) noted, studies on L2 motivation dominate the SLA/L2 research on individual differences. At the time of writing this editorial, a Google Scholar search of 'L2 motivation' has returned 933,000 results. Some of the articles included in this special issue of $J L E$ will add to this ever growing number.

Nowadays, a variety of perspectives on L2 motivation can be found in this flourishing area of applied linguistics research on language learner psychology. Among the recent most notable theoretical developments are the L2 Motivational Self System (L2MSS) framework proposed by Zoltán Dörnyei (2009) and Ema Ushioda's (2009) 'person-in-context relational view' on L2 motivation. Dörnyei's L2MSS draws on the theory of possible selves (Markus and Nurius, 1986) and the self-discrepancy theory (Higgins, 1987) while Ushioda's person-in-context perspective was influenced, among the multiplicity of socially rooted frameworks, by Vygotskian socio-cultural theory (Lantolf \& Thorne, 2006 cited in Ushioda, 2009). While rooted in different epistemological perspectives, these two theoretical approaches zoom our attention on individual language learner with his or her own aspirations, self-vision and goals.

The emphasis on a real and concrete language learners' agency and identity and the incorporation of a complex ever-shifting system of social relationships in defining and studying an individual learner's motivation in Ushioda's (2009) framework promotes qualitative methodologies. This marks a departure from the postpositivist L2 motivation research that has for several decades dominated the field. This principled attention to a concrete person rather than some abstract language learner has encouraged and enabled the appearance of other conceptual frameworks that focus on a particular and granular, rather than an abstracted and averaged, view of L2 motivation. Among more recent developments in this research vector is the Directed Motivational Currents (DMC) conceptual framework proposed by Zoltán Dörnyei, Christine Muir and Zana Ibrahim (2014). The framework draws some inspiration from Mihaly Csikszentmihalyi's (1980) highly influential concept of 'flow'. In this special issue, Ismail Xodabande and Esmat Babaii employed the DMC framework to explore motivational ebbs and flows experienced by an Iranian university student in his mobile assisted self-directed endeavour to learn German. The article has also highlighted the importance of being able to learn autonomously and to find ways to maintain passion and interest for learning a foreign language. Noting that the concept of learner autonomy has been linked to L2 motivation and higher academic achievements Lilia Raitskaya, Natalia Mekeko and Elena Golubovskaya conducted a systematic review of literature on learner autonomy. The authors explored the range and scope of such studies with the aim to distinguish the most influential publications on this psychological construct between the years 2011 and 2020.

To reflect a reality that psychological functions do not exist in isolation but form a complex systemic nexus with each other, explorations of emotions and affect have always been implicitly embedded in studies on psychological processes involved in language learning. However, the earliest principled investigations into emotion and affect in the language classroom were published only in the 1970s (MacIntyre \& Gardner, 1991). These studies were mostly concerned with the feeling of anxiety that students experienced in the L2 classroom. A strong impetus to this research direction was given when Elaine Horwitz and colleagues' (1986) published their Foreign Language Classroom Anxiety Scale. The research interest of SLA/L2 scholars in anxiety in the L2 classroom has not subsided over the following decades. At the time of writing this editorial piece, a Google Scholar search of keywords “'anxiety AND ‘second language learning’ yielded 45,200 results. “

This special issue will add up to the growing number of L2 studies on anxiety. Specifically, the two experimental studies by Meihua Liu and Shin Yi Chew and Yanqiu Chen, respectively, assessed levels of Chinese EFL learners' English language anxiety. The researchers also examined the role of technology use in reducing this feeling and enhancing the students' confidence to communicate in English. In recent years, L2 researchers have become increasingly aware of the presence of another ubiquitous negative emotion in the L2 classroom boredom. Studies on boredom are still scarce in the field of SLA. This special issue contributes to filling this 
gap. It includes a study by Mariusz Kruk who examined Polish EFL learners' ebbs and flows of boredom during classroom reading sessions. The author also assessed changes in the students' experience of boredom during the class time. In another study Muhammad Waleed Shehzad Khaled Besher Albesher, Sumaira Sarfraz and Shazma Razzaq examined boredom in the English language classroom in the context of Saudi Arabia. The author assessed the effects of boredom on various aspects of listening comprehension and performance.

With studies of anxiety dominating the SLA/L2 research agenda on emotion and affect for several decades, it was only a matter of time for research community to realize the need for a more encompassing vantage point on psychology of language learning - and teaching. In 2014, Peter MacIntyre and Sarah Mercer published their influential article Introducing positive psychology to SLA. This publication raised the awareness among the L2 research community that adopting a positive psychology perspective would enrich our understanding of language learners' - and their teachers' - emotional labours. This would also open up vistas for exploring a greater multitude of language learning and language teaching experiences. Acknowledging the importance and relevance of this call, this special issue includes a study by Nada Alqarni, who assessed levels of well-being, besides perceptions of stress, among English language educators in a university in Saudi Arabia. In the article by Elena Tikhonova, Marina Kosycheva and Galina Efremova the authors shift the focus to Russian educational context in their exploration of adaptation challenges faced by international students.

While general, social and educational psychology remain important feeder disciplines for SLA/L2 research, it could be argued that psychology of/for language learning is taking shape as a distinct field of scholarly inquiry. Mercer, Ryan and Williams (2012) identified a wide scope of research topics in this area which relate to "the mental experiences, processes, thoughts, feelings, motives, and behaviours of individuals involved in language learning" (p. 2). In this special issue, George Teoh Boon Sai explored emotional intelligence and its role in the process of learning English among Malaysian university students. The author also presented a case study of emotional tribulations and challenges encountered by a female student who had to combine her studies in a distance learning program with taking care of her large family. In a similar way that a language learning journey is filled with emotional experiences, the professional life of language educators is saturated with a wide range of emotions. In this special issue, Agnieszka Kałdonek-Crnjaković and Zrinka Fišer examined how Croatian English language educators positioned their students with dyslexia; the researchers also explored the roles the teachers assumed when working with this group of students.

Several authors in this special issue focus on L2 teachers' and learners' self-reported perceptions of various aspects pertaining to L2 education practice and learning. Abderrahim Mamad and Tibor Vígh share their study of Moroccan high school EFL teachers' perceptions and practices regarding traditional and alternative methods of assessment. Wallace Matthew explored levels of metacognition among Japanese EFL learners and the role of metacognition in the students' English listening performance. With questionnaires serving as the main tool for collecting data in studies on psychological and emotional aspects, SLA/L2 researchers continue contributing their efforts toward developing appropriate for the field instruments to measure language learners' - and their teachers' - beliefs, perceptions and attitudes. Considering major impacts that the fully online teaching and learning mode during the COVID-19 pandemic had produced on students and their teachers worldwide, Marco Cancino and Daniel Avila took up the task to explore Spanish-speaking EFL learners' perceptions of the fully online language learning environments. An article by María-Elena Gómez-Parra, Irina Golubeva and Roberto Espejo Mohedano reports on the process of constructing and validating a questionnaire to measure perceptions of intercultural practices among bilingual secondary schools students in several European countries.

To conclude, this special issue offers a mosaic of scholarly studies on psychological and emotional factors involved in learning and teaching an additional language. These studies have been done in diverse geographical and educational context and they adopted a variety of theoretical perspectives and methodological approaches. It is hoped that the research endeavours included in this special issue of Journal of Language and Education will contribute to a better understanding of psychological and emotional components which, while remaining hidden from the view, saturate language learners' and their teachers' educational experiences and professional practice.

This editorial piece aimed to locate the contents of this special issue within a wide and flourishing field of SLA/ L2 research on psychology of language learning and teaching. Hence, it was only possible to give a broad brush stroke overview of the main developments in this academic area. Many exciting research directions remain 
open for the future scholarly explorations. Drawing upon intellectual heritage left to us by Lev Vygotsky that was mentioned in the beginning of this editorial piece seems a particularly promising course of action. Vygotskian concepts of 'word meaning' (znachenie slova) and 'sense' (smysl) as well as 'perezhivanie' are currently being re-discovered by SLA/L2 researchers and language educators (Lantolf and Swain, 2019; Mok, 2015; Nikitina, 2020; Veresov, 2016). There is yet a wealth of discoveries to be made.

\section{References}

Arsenian, S. (1945). Bilingualism in the post-war world. Psychological Bulletin, 42(2), 65-86. https://doi. org/10.1037/h006171642, 65-86.

Csikszentmihalyi, M. (1990). Flow: The psychology of optimal experience. Harper \& Row.

Dörnyei, Z. (2009). The L2 Motivational Self System. In Z. Dörnyei, \& E. Ushioda (Eds.), Motivation, language identity and the L2 self (pp. 9-42). Multilingual Matters.

Dörnyei, Z., Muir, C., \& Ibrahim, Z. (2014). Directed motivational currents. In D. Lasagabaster, A. Doiz, \& J. M. Sierra (Eds.), Motivation and foreign language learning: From theory to practice (pp. 9-29). John Benjamins Publishing Company.

Gardner, R. C. (1985). Social psychology and second language learning: The role of attitudes and motivation. Edward Arnold.

Gardner, R. C. (1988). Attitudes and motivation. Annual Review of Applied Linguistics, 9, 135-148. https://doi. org/10.1017/S0267190500000854

Gardner, R. C., \& Lambert, W. E. (1959). Motivational variables in second-language acquisition. Canadian Journal of Psychology/Revue canadienne de psychologie, 13(4), 266-272. https://doi.org/10.1037/h0083787

Gardner, R. C., \& Lambert, W. E. (1972). Attitudes and motivation in second-language learning. Newbury House Publishers.

Higgins, E. T. (1987). Self-discrepancy: A theory relating self and affect. Psychological Review,94, 319-340. https://doi.org/10.1037/0033-295X.94.3.319

Horwitz, E. K., Horwitz, M. B., \& Cope, J. (1986). Foreign language classroom anxiety. The Modern Language Journal, 70(2), 125-132. https://doi.org/10.1111/j.1540-4781.1986.tb05256.x

Lantolf, J. P., \& Swain, M. (2019). Perezhivanie: The cognitive-emotional dialectic within the social situation of development. In Ali H. Al-Hoorie, \& Peter D. MacIntyre (Eds.), Contemporary Language Motivation Theory: 60 Years Since Gardner and Lambert (1959) (pp. 80-106). Multilingual Matters.

Lantolf, J. P., \& Thorne, S. L. (2006). Sociocultural theory and the genesis of second language development. Oxford University Press.

MacIntyre, P. D., \& Mercer, S. (2014). Introducing positive psychology to SLA. Studies in Second Language Learning and Teaching, 4(2), 153-172 https://doi.org/10.14746/ssllt.2014.4.2.2

MacIntyre, P. D., \& Gardner R. C. (1991). Methods and results in the study of anxiety and language learning: A review of the literature. Language Learning, 41(1), 85-117. https://doi.org/10.1111/j.1467-1770.1991. tb00677.x

Markus, H., \& Nurius, P. (1986). Possible selves. American Psychologist, 41(9), 954-969. https://doi. org/10.1037/0003-066X.41.9.954

Mercer, S., Ryan, S., \& Williams, M. (2012). Introduction. In S. Mercer, S. Ryan, \& M. Williams (Eds.), Psychology for language learning: Insights from research, theory and practice (pp.1-9). Palgrave Macmillan.

Mok, N. (2015). Toward an understanding of perezhivanie for sociocultural SLA research. Language and Sociocultural Theory, 2(2), 139-159. https://doi.org/10.1558/lst.v2i2.26428

Nikitina, L. (2020). Stereotypes and language learning motivation: A study of L2 learners of Asian languages. Routledge.

Ushioda, E. (2009). A person-in-context relational view of emergent motivation, self and identity. In Z. Dörnyei, \& E. Ushioda (Eds.), Motivation, language identity and the L2 self (pp. 215-228). Multilingual Matters.

Veresov, N. (2016). Perezhivanie as a phenomenon and a concept: Questions on clarification and methodological meditations. Cultural-Historical Psychology, 12(3), 129-148. https://doi.org/10.17759/chp.2016120308

Vygotsky, L.S. (1935). K voprosu o mnogoyazichii v detskom vozraste [The question of multilingual children]. In L. S. Vygotsky (Ed.), Sbornik statei (Selected writings) (pp.53-72). Gosudarstvennoe Uchebno-Pedagogicheskoye Izdatel'stvo.

Vygotsky, L. S. (1934). Myshlenie i rech: Psikhologicheskie issledovaniya [Thinking and speech: Studies in psychology]. Gosudarstvennoe Sotsialno-Ekonomicheskoe Izdatel'stvo. 